\title{
Bronchial lability in cystic fibrosis
}

\author{
GILLIAN DAY^ and MARGARET B. MEARNS \\ From Queen Elizabeth Hospital for Children, London
}

\begin{abstract}
Day, G., and Mearns, M. (1973). Archives of Disease in Childhood, 48, 355. Bronchial lability in cystic fibrosis. Bronchial lability was studied in $\mathbf{5 2}$ children with cystic fibrosis (CF) and assessed by changes in the peak expiratory flow measured before, during, and after running. The findings are discussed in relation to the severity of pulmonary involvement assessed clinically and radiologically, and with those found in asthmatic children and those with a history of wheezy bronchitis in early childhood.

In patients with $\mathrm{CF}$, bronchial lability was found even in those with minimal pulmonary involvement. The lability was due not only to bronchoconstriction but to a dilatation which was greater than occurs in normal and asthmatic children; this dilatation increased with the severity of the disease.

Only 14 of 52 children with CF had results within the normal range for all indices; $50 \%$ had abnormal bronchodilatation during exercise and $46 \%$ had abnormal bronchoconstriction after exercise.
\end{abstract}

Results of pulmonary function tests in cystic fibrosis (CF) were first reported in 1954 (West, Levin, and di Sant'Agnese) when it was shown that the characteristic finding was difficulty in moving air rapidly in or out of the lungs. It is now well accepted that the earliest detectable abnormality of pulmonary function in this disease is airways obstruction. There is also evidence that the incidence of atopic sensitivity is greater in patients with CF than in the normal population. Kulczycki, Mueller, and Shwachman (1961) reported evidence of respiratory allergy in $16 \cdot 2 \%$ of 266 patients, and McCarthy, Pepys, and Batten (1969) found that $50 \%$ of 37 patients tested had positive skin test reactions to common allergens. The majority of asthmatic children have a characteristic response to exercise: that is bronchodilatation followed by bronchoconstriction (Jones, Buston, and Wharton, 1962). These changes have been termed bronchial lability. The present study was designed to determine the pattern of bronchial lability on exercise in patients with $\mathrm{CF}$ and to compare this with the pattern in normal and asthmatic children. In a previously reported study (Heimlich, Strick, and Busser, 1966) no difference in the bronchial lability of normal children and those with CF was shown; this is contrary to our findings.

Received 15 August 1972.

^Present address: Hospital for Sick Children, Toronto, Canada.

\section{Material}

Fifty-two children, whose ages ranged from $4 \frac{1}{2}$ to 17 years 10 months and who attended the Cystic Fibrosis clinic at the Queen Elizabeth Hospital between March and July 1971 , were studied. 32 were boys and 20 were girls. These children were free of acute infection and their disease was in a stable state. On the basis of clinical and radiological findings they were placed into 3 groups as previously described (Jackson and Young, 1960).

Group I (mild) (25 patients). Good general healthperhaps occasional attacks of bronchitis: chest $x$-ray normal or with minimally thickened bronchial wall pattern.

Group II (moderate) (13 patients). Good general health-sometimes productive cough. Localized change on chest $x$-ray.

Group III (severe) (14 patients). Persistent pulmonary infection with purulent sputum: generalized changes in chest $x$-ray.

\section{Method}

Before the tests all the children were given routine percussion drainage by the physiotherapist and then they rested for half-an-hour.

Forced vital capacity (FVC) and forced expiratory volume at one second $\left(\mathrm{FEV}_{1 \cdot 0}\right)$ were measured using a spirometer of the type described by Bernstein, D'Silva, and Mendel (1952), and expressed as a percentage of 
TABLE I

Mean values and standard deviation for age, $P E F, F E V_{1 \cdot 0}$, and $F V C$ in relation to clinicoradiological assessment of severity of cystic fibrosis (see text)

\begin{tabular}{|c|c|c|c|c|}
\hline Group & Age & $\begin{array}{c}\text { PEF } \\
(\% \text { of normal) }\end{array}$ & $\begin{array}{c}\text { FEC } \\
(\% \text { of normal) }\end{array}$ & $\begin{array}{c}\text { FVC } \\
(\% \text { of normal })\end{array}$ \\
\hline $\begin{array}{l}\text { I (mild) (25 patients) } \\
\quad \text { Mean } \\
\text { SD }\end{array}$ & $\begin{array}{r}10 \cdot 4 \\
3 \cdot 5\end{array}$ & $\begin{array}{l}87 \cdot 3 \\
28 \cdot 2\end{array}$ & $\begin{array}{l}69 \cdot 3 \\
19 \cdot 3\end{array}$ & $\begin{array}{l}75 \cdot 5 \\
14 \cdot 8\end{array}$ \\
\hline $\begin{array}{l}\text { II (moderate) (13 patients } \\
\text { Mean } \\
\text { SD }\end{array}$ & $\begin{array}{r}10 \cdot 8 \\
2 \cdot 7\end{array}$ & $\begin{array}{l}73 \cdot 3 \\
22 \cdot 0\end{array}$ & $\begin{array}{l}64 \cdot 9 \\
18 \cdot 0\end{array}$ & $\begin{array}{l}70 \cdot 8 \\
14 \cdot 1\end{array}$ \\
\hline $\begin{array}{l}\text { III (severe) (14 patients) } \\
\text { Mean } \\
\text { SD }\end{array}$ & $\begin{array}{r}13 \cdot 0 \\
3 \cdot 5\end{array}$ & $\begin{array}{l}54 \cdot 4 \\
15 \cdot 3\end{array}$ & $\begin{array}{r}41 \cdot 1 \\
8 \cdot 8\end{array}$ & $\begin{array}{r}53 \cdot 5 \\
8 \cdot 6\end{array}$ \\
\hline
\end{tabular}

predicted normal for height as given by Strang (1959). Peak expiratory flow (PEF) was measured by a Wright's Peak Flow Meter; normal values were taken from the data of Nairn et al. (1961).

The children ran for 6 minutes in the corridor. PEF was measured before and at 2-minute intervals both during exercise and for 15 minutes after stopping. In each case the best of three reproducible efforts was recorded. The pulse rate was recorded at the end of the exercise to determine that the exercise had been sufficient to give a heart rate greater than $170 / \mathrm{min}$.

The changes induced by exercise in PEF have been expressed in the following ways (Anderson, Connolly, and Godfrey, 1971):

(a) Percentage Rise Index given by, $\frac{\text { Highest PEF }- \text { Resting PEF }}{\text { Resting PEF }} \times 100(\%)$

(b) Percentage Fall Index given by, Resting PEF-Lowest PEF Resting PEF

where the highest PEF was that obtained during exercise and the lowest PEF was the lowest overall obtained either during exercise or in the 15 minutes afterwards.

(c) Exercise Lability = Percentage Rise Index + Percentage Fall Index

(d) 'Modified' Jones Lability Index (Jones and Jones, 1966)

$$
\frac{\text { Highest PEF }- \text { Lowest PEF }}{\text { Expected Normal PEF }} \times 100(\%)
$$

where the lowest PEF was as in (b).

The Jones Lability Index was modified by the use of PEF instead of $\mathrm{FEV}_{1 \cdot 0}$ and without administration of bronchodilators.

The normal values for these indices were based on the studies of Silverman and Anderson (1972); values above those given below were regarded as outside the normal range.

Percentage Rise Index

Percentage Fall Index

Exercise Lability Index

$>17 \%$

$>10 \%$

Modified Jones Lability Index
$>22 \%$

$>22 \%$

\section{Results}

The mean age in Groups I and II was similar $(10.4$ years and 10.8 years, respectively); the patients in Group III were older, with a mean age of 13 years. Simple tests of ventilatory capacity showed a significant difference between Groups I and III, the mean FVC being $75 \%$ and $53 \%$ respectively, and the mean $\mathrm{FEV}_{1.0} 69 \%$ and $41 \%$, the values obtained in these tests showing a decrease with the increasing severity of the pulmonary involvement (Table I).

Changes in PEF induced by exercise. $65 \%$ of all the patients (34 of 52) had an abnormal exercise lability, this abnormality being less frequent in Group I than in the other groups. 26 of the 52 patients had an abnormal Percentage Rise Index, and in 15 this was not associated with an abnormal Percentage Fall Index. 24 patients had an abnormal Percentage Fall Index and in half of these this abnormality was not associated with an abnormal Percentage Rise Index.

Proportionately more patients in Group III (42\%) had an abnormal Percentage Rise Index, and a greater proportion of patients in Group II (46\%) had an abnormal Percentage Fall Index than in the other groups. Patients having both abnormal Percentage Rise and Fall Indices were evenly distributed between the 3 groups (Table II).

Modified Jones Lability Index. 23 of the 52 patients (44\%) studied were found to have an index greater than $22 \%$. In 13 of 25 patients in Group I, 6 of 13 patients in Group II, and 4 of 14 patients in Group III $(52 \%, 46 \%$, and $21 \%$, respectively) the index was greater than $22 \%$ (Table III). 
TABLE II

Abnormal Percentage Rise and Percentage Fall Indices and Exercise Lability in relation to severity of disease

\begin{tabular}{l|c|c|c}
\hline & $\begin{array}{c}\text { Group I } \\
\text { (mild) }\end{array}$ & $\begin{array}{c}\text { Group II } \\
\text { (moderate) }\end{array}$ & $\begin{array}{c}\text { Group III } \\
\text { (severe) }\end{array}$ \\
\cline { 1 - 3 } & $\begin{array}{c}\text { (\% of } 25 \\
\text { patients })\end{array}$ & $\begin{array}{c}\text { (\% of 13 } \\
\text { patients })\end{array}$ & $\begin{array}{c}\text { (\% of 14 } \\
\text { patients })\end{array}$ \\
\hline $\begin{array}{c}\text { Abnormal Percentage } \\
\text { Fall Index only }\end{array}$ & 20 & 46 & 14 \\
$\begin{array}{c}\text { Abnormal Percentage } \\
\text { Rise Index only }\end{array}$ & 24 & 23 & 42 \\
$\begin{array}{c}\text { Abnormal Percentage } \\
\text { Rise and Fall indices }\end{array}$ & 20 & 23 & 21 \\
$\begin{array}{c}\text { Abnormal Exercise } \\
\text { Lability }\end{array}$ & 52 & 85 & 72 \\
\hline
\end{tabular}

TABLE III

Lability Index using a modification of the Jones Index (normal value $<22$ ) in relation to severity of disease

\begin{tabular}{|c|c|c|c|}
\hline $\begin{array}{l}\text { 'Modified' } \\
\text { Jones } \\
\text { Lability } \\
\text { Index }\end{array}$ & $\begin{array}{l}\text { Group I } \\
\text { (mild) } \\
(\% \text { of } 25 \\
\text { patients) }\end{array}$ & $\begin{array}{l}\text { Group II } \\
\text { (moderate) } \\
\text { ( }{ }^{\circ} \text { of } 13 \\
\text { patients) }\end{array}$ & $\begin{array}{c}\text { Group III } \\
\text { (severe) } \\
\left(\begin{array}{c}0 \\
\%\end{array} \text { of } 14\right. \\
\text { patients) }\end{array}$ \\
\hline \multicolumn{4}{|l|}{ Normal } \\
\hline 15 & 24 & 16 & 51 \\
\hline $15-21$ & 24 & 38 & 21 \\
\hline \multicolumn{4}{|l|}{ Abnormal } \\
\hline $22-29$ & $24\}_{56}$ & $23]_{46}$ & $14 \succ_{28}$ \\
\hline 29 & $28\}^{50}$ & $23 \int^{46}$ & $14 \int^{28}$ \\
\hline
\end{tabular}

Comparison of Percentage Rise and Percentage Fall in relation to initial PEF (Table IV). Only $25.5 \%$ of those patients with an initial PEF greater than $75 \%$ of predicted normal

TABLE IV

Change in PEF in relation to the resting values and severity of disease

\begin{tabular}{|c|c|c|}
\hline & $\begin{array}{c}\mathrm{PEF}>75^{\circ} \text { of } \\
\text { normal ( } \% \text { of } \\
23 \text { patients })\end{array}$ & $\begin{array}{c}\text { PEF }<75 \% \text { of } \\
\text { normal ( } \% \text { of } \\
29 \text { patients) }\end{array}$ \\
\hline $\begin{array}{l}\% \text { rise } \\
\text { Group I (mild) } \\
\text { II (moderate) } \\
\text { III (severe) }\end{array}$ & $\begin{array}{l}17 \\
8 \cdot 5 \\
0\end{array}$ & $\begin{array}{l}24 \\
14 \\
31\end{array}$ \\
\hline Total & $25 \cdot 5$ & 69 \\
\hline $\begin{array}{l}\% \text { fall } \\
\text { Group I (mild) } \\
\text { II (moderate) } \\
\text { III (severe) }\end{array}$ & $\begin{array}{r}17 \\
13 \\
0\end{array}$ & $\begin{array}{l}17 \\
14 \\
17\end{array}$ \\
\hline Total & 30 & 48 \\
\hline
\end{tabular}

had an abnormal ${ }_{0}^{\circ}$ rise, but this index was greater than normal in $69 \%$ of 29 patients whose initial PEF was less than $75^{\circ}$ of the predicted normal.

The Percentage Fall was greater than normal in $30 \%$ of the patients whose initial PEF was more than $75^{\circ} \%$ of normal and in $48^{\circ} \%$ of those with peak flows less than $75^{\circ}$ o of normal.

Distribution of the Percentage Rise and Fall in PEF. The distribution of lability in this study of CF patients has been compared with the distribution of values in normal and asthmatic children as reported by Silverman and Anderson (1972).

The distribution of percentage rise differed from that of normal children, and the trend was similar to that of asthmatics. The distribution of percentage fall was abnormal, but the range was not as extreme as occurs in asthma (Fig. 1 and 2).

Exercise lability $\left(\%\right.$ rise plus ${ }^{\circ}$, fall. Exercise lability has been reported in normal children and in those with a past history of wheezy bronchitis with or without asthma (König, Godfrey, and Abrahamov, 1972) and the results found in the present study have been compared with those. Exercise lability is greater in CF than in normal children or in those with past history of wheezy bronchitis, but less than in asthmatic children. This exercise lability in CF increased with increasing severity of pulmonary involvement.

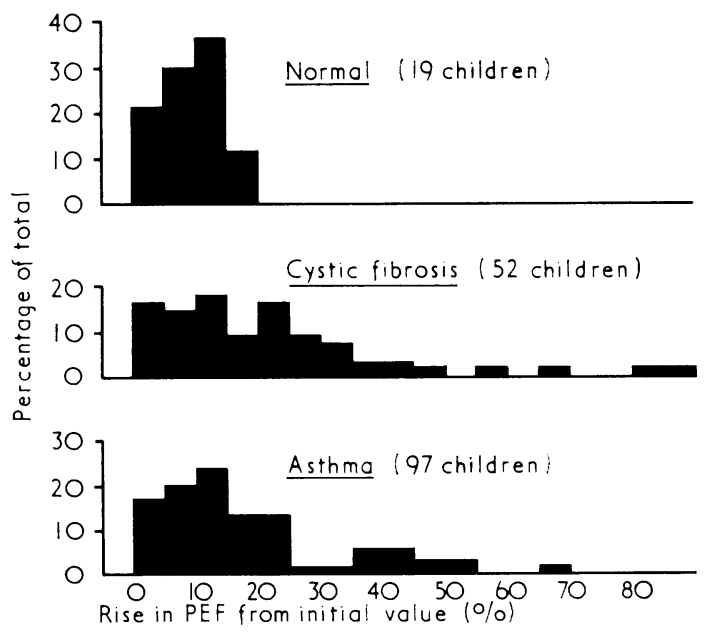

FIG. 1.-Distribution of percentage rise in peak flow in children with cystic fibrosis compared with normal and asthmatic children. (Normal and asthmatic values from Silverman and Anderson, 1972.) 

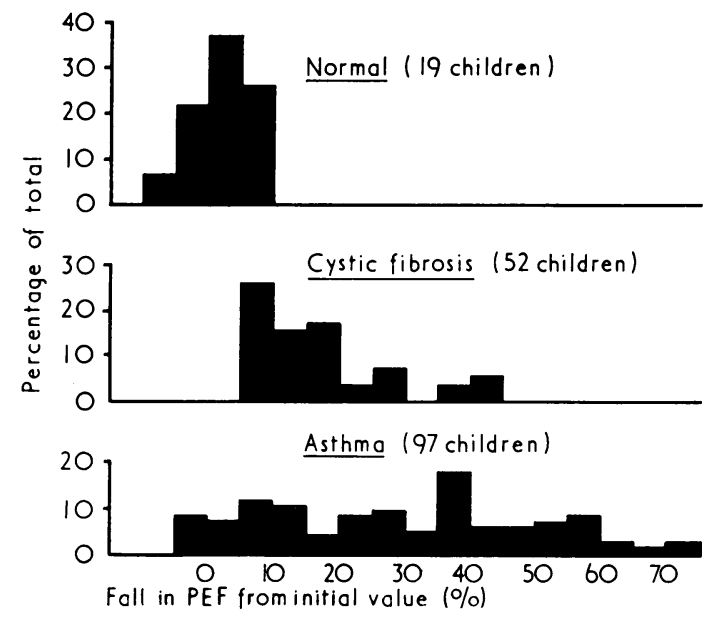

Fig. 2.-Distribution of percentage fall in peak flow in children with cystic fibrosis compared with normal and asthmatic children. (Normal and asthmatic values from Silverman and Anderson, 1972.)

The percentage rise component of the exercise lability was greatest in $\mathrm{CF}$, the percentage fall component was above the normal in all the disease entities but was much greater in the asthmatics (Fig. 3).

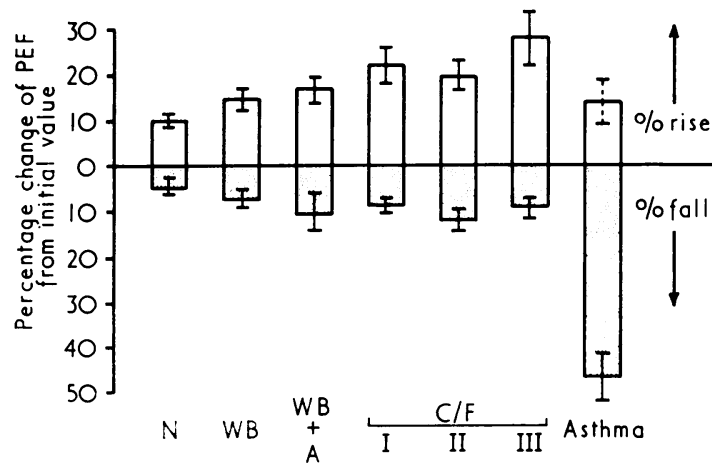

FIG. 3.-Exercise lability. Effect of exercise in causing a rise or a fall in PEF in cystic fibrosis $(C F, 3$ grades of severity), wheezy bronchitis (WB) with or without asthma $(A)$ and in normal $(N)$. (Data other than for $C F$ from König et al., 1972.)

\section{Discussion}

An increased bronchial lability on exercise was found in the majority of the CF patients in this study, and these findings are contrary to those previously reported (Heimlich et al., 1966) which found children with $\mathrm{CF}$ to be indistinguishable from the normal controls. However, those child- ren were studied walking at 3 miles per hour on a treadmill with a $10^{\circ}$ slope, and walking is not such an effective method of demonstrating exercise bronchial lability as running (Silverman and Anderson, 1972).

In the present study, the increased exercise lability was due more to dilatation than constriction, though 24 of the 52 patients had a constrictive component of lability greater than normal. Increased dilatation was more frequent in the patients with severe pulmonary involvement and proportionately more Group III patients had an abnormal exercise lability when compared with Group I patients. Comparison of the modified Jones Lability Index in these clinicoradiological groups suggested the contrary, i.e. proportionately less patients in Group III had an increased bronchial lability when compared with patients in Group I. In the calculation of the Jones Lability Index the changes which occur in the PEF on exercise are related to the predicted normal values rather than the resting value of the PEF; the degree of change being thus minimized in patients with resting values much lower than predicted values, as in the majority of the severely affected patients.

A highly significant correlation between the resting PEF and the percentage rise on exercise exists in adult asthmatics, and in the present study patients with $\mathrm{CF}$ behaved in a similar manner. A greater proportion of CF patients whose resting PEF was below $75 \%$ of predicted normal showed an abnormal percentage rise than those with the higher resting PEF values.

The exercise lability of children with a history of wheezy bronchitis with or without asthma in the first 5 years of life was found to be increased, and they also showed more dilatation than constriction (König et al., 1972). The changes in the $\mathrm{CF}$ children were similar to but greater than those in the wheezy children. Had the changes in CF only been present in the more severely affected patients, it could be supposed that they were the result of structural changes in the lungs; but the abnormality was found in some patients without persisting cough and whose chest $x$-rays were normal or showed minimal thickened bronchial wall pattern, and whose $\mathrm{FEV}_{1 \cdot 0}, \mathrm{FVC}$, and FEV/ FVC ratio were within the predicted normal range. Again these findings are unlike those reported in patients with bronchitis and bronchiectasis (who may be presumed to have structural changes) where the effects of exercise or bronchial lability were small or absent (Jones, Wharton, and Buston, 1963).

The explanation for this increase of bronchial lability on exercise in CF has still to be determined. 
McCarthy et al. (1969) have shown an increased skin reactivity to common allergens in CF children, the majority being without clinical manifestations of reactions due to them, and they consider these patients to be immunologically different from both the normal and from the atopic subject. The response to exercise also differs from that of asthmatics in that there was a greater bronchodilatation associated with a smaller degree of bronchoconstriction. The sex ratio also differed: in asthmatic children the male : female ratio has been found to be 2 or $3: 1$. In the present series of children with CF, abnormal bronchoconstriction, as shown by an abnormal Percentage Fall Index, occurred in $31 \%$ of the males and $60 \%$ of the females giving a ratio of $1: 2$, the reverse of that found in asthma. The pattern of the bronchial lability in CF was similar to that found in patients with an early history of wheezy bronchitis, and perhaps suggests that in these two conditions there may be some inherent difference in the bronchial lability of patients compared with that of the normal population, or that latent bronchial lability has been unmasked by infection or some other factor occurring at an earlier age.

The authors thank Drs. G. Godfrey, P. König, M. Silverman, and Sandra Anderson for helpful discussions and for allowing the results of their own studies to be used for comparison.

M.B.M. is in receipt of a grant from the Cystic Fibrosis Trust.

\section{REFERENCES}

Anderson, S. D., Connolly, N. M., and Godfrey, S. (1971). Comparison of bronchoconstriction induced by cycling and running. Thorax, 26, 396.
Bernstein, L., D'Silva, J. L., and Mendel, D. (1952). The effect of the rate of breathing on the maximum breathing capacity determined with a new spirometer. Thorax, 7, 255.

Heimlich, E. M., Strick, L., and Busser, R. J. (1966). An exercise response test in childhood asthma. (Abst.) fournal of Allergy, 37, 103.

Jackson, A. D. M., and Young, W. F. (1960). Cystic fibrosis of the pancreas. In Die Prognose Chronischer Erkrankungen. Ed. by F. Linneweh. Springer, Berlin.

Jones, R. H. T., and Jones, R. S. (1966). Ventilatory capacity in young adults with a history of asthma in childhood. British Medical fournal, 2, 976.

Jones, R. S., Buston, M. H., and Wharton, M. J. (1962). The effect of exercise on ventilatory function in the child with asthma. British Fournal of Diseases of the Chest, 56, 78.

Jones, R. S., Wharton, M. J., and Buston, M. H. (1963). The place of physical exercise and bronchodilator drugs in the assessment of the asthmatic child. Archives of Disease in Childhood, 38, 539.

König, P., Godfrey, S., and Abrahamov, A. (1972). Exerciseinduced bronchial lability in children with a history of wheezy bronchitis. Archives of Disease in Childhood, 47, 578.

Kulczycki, L. L., Mueller, H., and Shwachman, H. (1961). Respiratory allergy in patients with cystic fibrosis. Fournal of the American Medical Association, 175, 358.

McCarthy, D. S., Pepys, J., and Batten, J. (1969). Hypersensitivity to fungi in cystic fibrosis. In Proceedings of the 5th International Cystic Fibrosis Conference, Cambridge, p. 194. Ed. by D. Lawson. Cystic Fibrosis Trust, London.

Nairn, J. R., Bennet, A. J., Andrew, J. D., and MacArthur, P. (1961). A study of respiratory function in normal school children. The peak flow rate. Archives of Disease in Childhood, 36, 253.

Silverman, M., and Anderson, S. D. (1972). Standardization of exercise tests in asthmatic children. Archives of Disease in Childhood, 47, 882 .

Strang, L. B. (1959). Ventilatory capacity of normal children. Thorax, 14, 305.

West, J. R., Levin, S. M., and di Sant'Agnese, P. A. (1954). Pulmonary function in cystic fibrosis of the pancreas. Pediatrics, 13, 155 .

Correspondence to Dr. Margaret B. Mearns, Queen Elizabeth Hospital for Children, Hackney Road, London E2 8PS. 